\title{
Lincoln's Miniature Bible: Performing Sacred History IN THE GETTYSBURg ADDRESS
}

\begin{abstract}
Analysts of Abraham Lincoln's Gettysburg Address have noted its reliance on religious and liturgical language and motifs, but have not fully recognized the intricate way in which is mimics the Bible, replicating the "U-shape" of "type" and "antitype" that Northrop Frye and others have identified as the structuring principle of Christian Scripture. Elaborating this schema with remarkable care, Lincoln in effect re-creates sacred or "salvation" history in miniature, casting the ephemeral words and event of the moment as the focal point of human destiny. The resulting dialectical tension, which counterposes the fleeting or disposable to the profoundly important, refutes - but was also carried forward - in the popular legend that the address was hastily written on the back of an envelope. In other instructive ways, too, it helped to generate the mythic meanings that Americans have attached both to the address and to Lincoln himself.
\end{abstract}

Keywords

Abraham Lincoln; Gettysburg Address; American Civil War; Bible; Christianity; political rhetoric; Walt Whitman; William H. Herndon

Of the various texts that make up America's patriotic secular canon, among the best known is President Abraham Lincoln's Gettysburg Address. This is due in no small part to the fact that generations of schoolchildren were expected to learn this short speech of just 272 words by heart. Those words have also been cast in bronze and carved into marble, framed and hung on thousands of walls, featured prominently on film (as in the opening scene of Stephen Spielberg's Lincoln), and set to grand orchestral music. They have even been sold as an imitation illuminated manuscript modeled on medieval Bibles (Figure 1). ${ }^{1}$ 
Such an homage, giving Lincoln's words the "look" of sacred Scripture, obviously reflects their enormous prestige. Further, though, it reflects a truth about the address and its popular reception. In America, the cultural resonance of The Gettysburg Gospel - as one book-length study calls it - rivals that of the Bible's most treasured short passages: the Twenty-Third Psalm, the Lord's Prayer, the Sermon on the Mount, Luke's Nativity story, and that popular choice of wedding texts, First Corinthians 13. Creating a visual resemblance to Scripture also points up the verbal resemblance: The phrasings and cadences of the address owe much to the King James Bible and the Anglican Book of Common Prayer, as detailed in yet another of the many critical works that study it closely (Elmore 2009). ${ }^{2}$

For all the attention to these features, however, the "biblicality" of the Gettysburg Address, both as text and as cultural event, has yet to be fully appreciated in all its criss-crossing dimensions. In important ways Lincoln was not just borrowing from Scripture but reproducing it, retracing the arc of the great sacred story to tell a second story - one that resembled and paralleled the Christian scheme that contained it but was centered on America, his own listeners, and the wartime events that called forth the address. As this essay will try to show, the result within the speech itself is a structure of remarkable intricacy and internal parallels, a rhetorical design with a shape like that of the biblical Testaments and a similar insistence on finding the greatest in the least. Moreover, the cultural reception of the Gettysburg Address, and of Lincoln himself, would cast them both in that same light: as demonstrations of a surprising mutual dependence between the rough, crude and transitory and things of supreme importance.

Lincoln himself obviously knew that he was writing in an idiom that could be perceived as sacred, or to use his own word, "hallowed." At the same time, the text itself famously asserts its own ephemerality: "The world will little note, nor long remember what we say here." It is not only very short, but written in an economical style that has been called "telegraphic," perhaps reflecting Lincoln's admiration for telegraphy and his long experience at that point with dispatching military orders by telegraph (Wills 1992: 169-171). Those messages were, necessarily, concise and unembellished to the point of bluntness, and the sentences of the Gettysburg Address likewise contrast in striking ways with conventional nineteenth-century oratory - for instance, Edward Everett's much longer address at the same event, which sounded some of the same themes as Lincoln's but in a far more leisurely style:

Standing beneath this serene sky, overlooking these broad fields now reposing from the labors of the waning year, the mighty Alleghenies dimly towering before us, the graves of our brethren beneath our feet, it is with hesitation that I raise my poor voice to break the eloquent silence of God and Nature.

That is Everett's opening sentence, and within his 58 paragraphs are individual sentences which, at their longest, are more than half the length of Lincoln's entire address. 


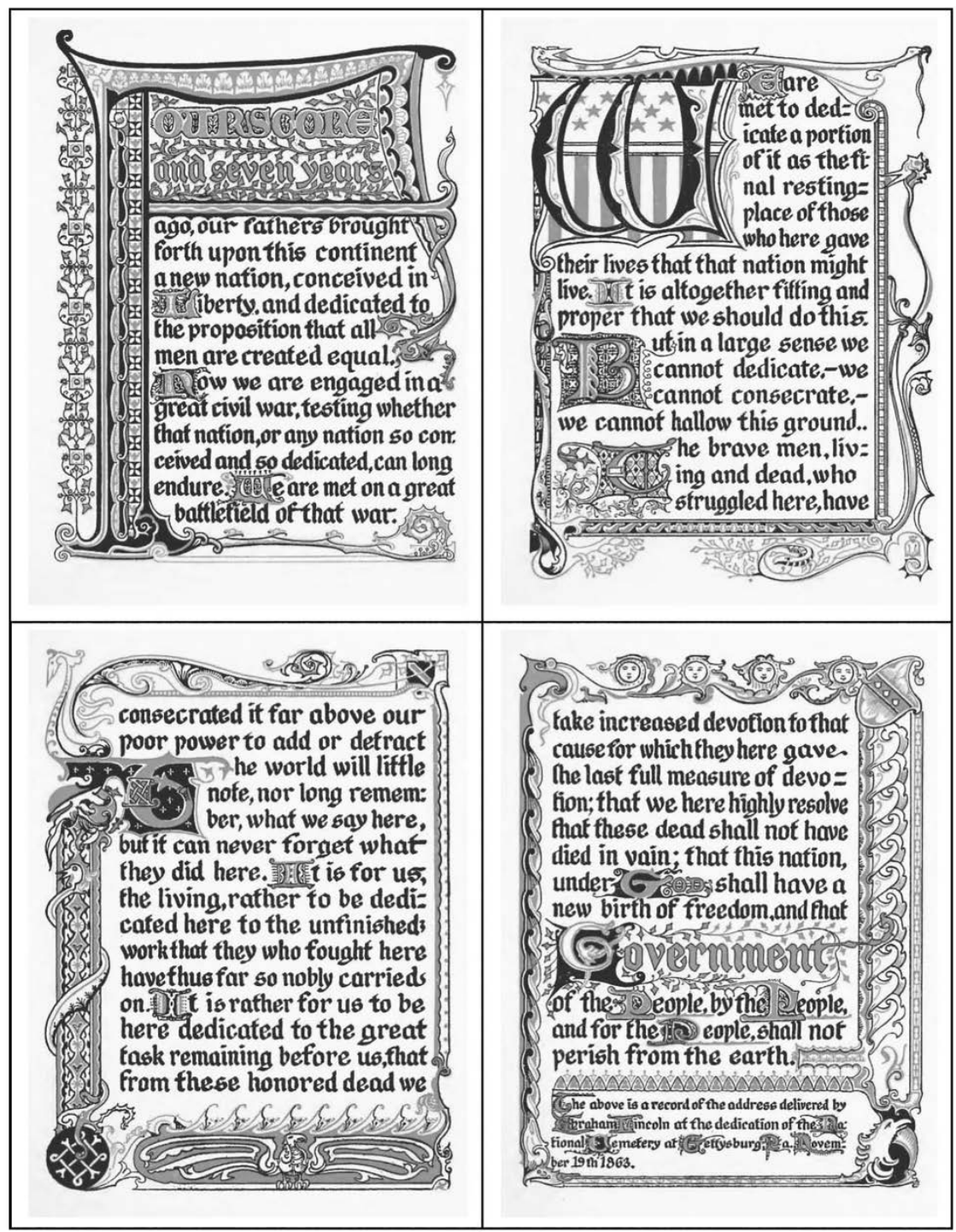

Figure 1. The Gettysburg Address as illuminated manuscript, 1919

Though it had its admirers from the start, among them Ralph Waldo Emerson (Elmore 2009: 11), Lincoln's prediction that the address would not long be remembered seemed at first likely to come true. The speech took a generation or so to enter the secular canon, and until it did, the Lincoln texts that were framed and hung on walls were the Emancipation Proclamation - a military directive, technically, without much literary flourish - and his proclamation of the first official Thanksgiving Day, sometimes recast as the words of a hymn. Historian Gabor Boritt notes the irony: 
The Proclamation and the Hymn were probably the most reproduced Lincoln documents of the war. ... Indeed, compared to [these], his remarks at Gettysburg shrank to modest significance. On the very day Lincoln spoke at the cemetery, newspapers around the country that would ignore those words printed his Proclamation, or his Hymn, or both. (Boritt 2006: 165, 167)

Eventually, "his half dozen words of consecration," as his own secretary casually called them - words described in the Gettysburg ceremony's official program merely as "Dedicatory Remarks," as opposed to Everett's headline "Oration" would hang beside or even supplant these grand public acts. Perhaps this would have pleased Lincoln; it almost surely would have surprised him (Boritt 2006: 185; Address 1864).

Early on, a famous legend developed that Lincoln had written the address as a kind of afterthought, hastily scrawling it on the back of an envelope while on board the train to Gettysburg. In fact, the best evidence suggests that like his other public statements, it was carefully prepared in advance. ${ }^{3}$ The legend is nonetheless highly revealing: It associates the enduring value of the speech with its supposedly haphazard composition, grounding its quasi-sacredness in its humble origins and in the "tall, homely ... simple, rude, majestic" figure who delivered it, in the words of one report on which the legend was apparently founded (Arnold 1866: 423). Another of those reports made the paradoxical link of sacred to mundane explicit: "[Lincoln's] remarks at Gettysburg, which have been compared to the Sermon on the Mount, were written in the [train] car on his way from Washington to the battlefield, upon a piece of pasteboard held on his knee, with persons talking all around him" (Poore 1888: 228).

As versions of this story made their way into schoolrooms, they reached the fiction writer Mary Raymond Shipman Andrews, who embroidered them further to produce her 1906 novella The Perfect Tribute - her best-remembered work and, by some reports, the bestselling of all books about Lincoln for decades (Peterson 1994: 115). Taught in schools itself, like the address, and adapted twice for film and television, Andrews' immensely popular tale has instructed several generations in this celebrated bit of Lincoln lore.

Dramatizing the early reports of makeshift improvisation, Andrews gives us the image that stuck in the public mind as the "back of the envelope." She also enlarges on the contrast between the rude and majestic in Lincoln's own person, retrojecting the paradox of the speech into the character of its author. In her fictionalized telling, Lincoln struggles to write the address with a gloomy sense that he is unequal to the task. Sitting on the train, he notes the contrast between Everett, the scholarly, well-bred "finished gentleman" who would deliver the event's keynote, and his own "rough-hewn" self: "of what use was it for such a one to try to fashion a speech fit to take a place by the side of Everett's silver sentences? $\mathrm{He}$ sighed" (Andrews 1906: 4-5). Resigning himself to do his modest best, he looks about the train car for writing materials and notices that Secretary of State Seward has just unwrapped some books. On a bit of the brown wrapping paper, "torn carelessly in a zig-zag," and with "the untidy stump of a pencil," Lincoln labors 
to chisel the speech "from the rock of his sincerity." He continues this painful toil all too aware that he lacks Everett's artistry with words, which seems to him like a brilliant musician's skill at a keyboard (5-9).

As the story continues, the party arrives at Gettysburg, Lincoln delivers the speech, receives no applause or "sound of approval," and with further shakened confidence he concludes glumly that it "must have been pretty poor stuff" (17, 21). Only later, in a chance meeting with a Confederate prisoner who is dying of wounds from the battle, does he learn what a profound impact it apparently has had across the whole divided nation. The crowd's silence, it turns out, was awe: "One might as well applaud the Lord's Prayer - it would have been sacrilege," the admiring young soldier explains to him (40). ${ }^{4}$

An envelope is paper designed to contain other paper, the text on it normally not the message itself but instructions for delivering one. That the "envelope" in Andrews' story was merely wrapping paper both heightens the point and makes it more ironic. Wrapping paper might not carry any text at all, and if it wrapped books, then its intended use was to protect works that do. The books were valuable enough to be wrapped, yet thanks to Lincoln, what gets written on the temporary wrapping, after it has been tossed aside, will far exceed in value anything contained in the books. The scrap of brown paper is obviously meant to resemble Lincoln himself: a "rough-hewn," seemingly inadequate, yet ready medium for an expression of transcendent meaning.

Central to the popular myth of the Gettysburg Address, in other words, is a dialectical relationship between the utterly disposable and the profoundly important, a relationship in which material of the most minor and temporary value, having already been used up and discarded, mediates the drafting of a text on a par with the Lord's Prayer - and to the author's own surprise, as one might expect if he was operating under something like divine inspiration. That this is apparently not what happened makes the story all the more instructive, a window onto what Americans have looked to the address hoping to find. Yet at the same time, the "back of the envelope" legend does reflect something that is genuinely there in the text. The structure of the address presents us with essentially that same dialectic: a remarkably intricate scheme in which the enduring and sacred give meaning to a transitory moment, which in turn provides the occasion on which the sacred is performed and brought to life.

The basic movement within the text is a simple one-cycle oscillation, beginning and ending with a panoramic view of all human history, and descending from this through ever-narrower levels to alight, briefly, on the address itself and the moment of its delivery, before then re-achieving the grand vision. Those intermediate levels identify a sacred trust, one that America's history delivers to Americans of the present and calls on them to carry into the future on behalf of all humankind. The address and its immediate occasion are mere, momentary, passing reminders, the plain brown wrapper through which the sacred trust is conveyed. That, however, is not Lincoln's own metaphor. His controlling image is ground or territory, with each step forward in time taking us first toward ever narrower ground and then, 
in the second half of the cycle, toward ever wider, until in the final two words we finish where we implicitly began, on the widest territory of all: "the earth."

These movements and relationships readily become apparent from a close look at the way the address is structured. Analysts have already shown that the logic of the argument follows a pattern of birth and baptism, death, and rebirth, a schema that Lincoln would have known well from Christian teachings and especially the Anglican liturgy (Elmore 2009: 24-35, 47-51; Wills 1992: 62). This pattern accounts for its basic shape. In fact, though, the plan is more intricate than that. It develops almost line-by-line in such a way that each individual element in the second half of the cycle mirrors and matches one in the first (Figure 2). ${ }^{5}$

Implicit in Lincoln's famous opening is the view that the world at large, presumably for all its previous history, had been under the dominion of governments that were not conceived in liberty or equality - tyrannies, that is, of one sort or another. Then, "Fourscore and seven years ago," in one part of the world ("on this continent"), something happened that changed the course of that history: a new nation was born, "brought forth," dedicated to exactly those values. We then jump to the present, "now," when that nation and its values are undergoing their severest test. That "now" refers generally to the current situation; Lincoln was speaking in the war's $32^{\text {nd }}$ month. The next step, however, takes us to a narrower now, the day of

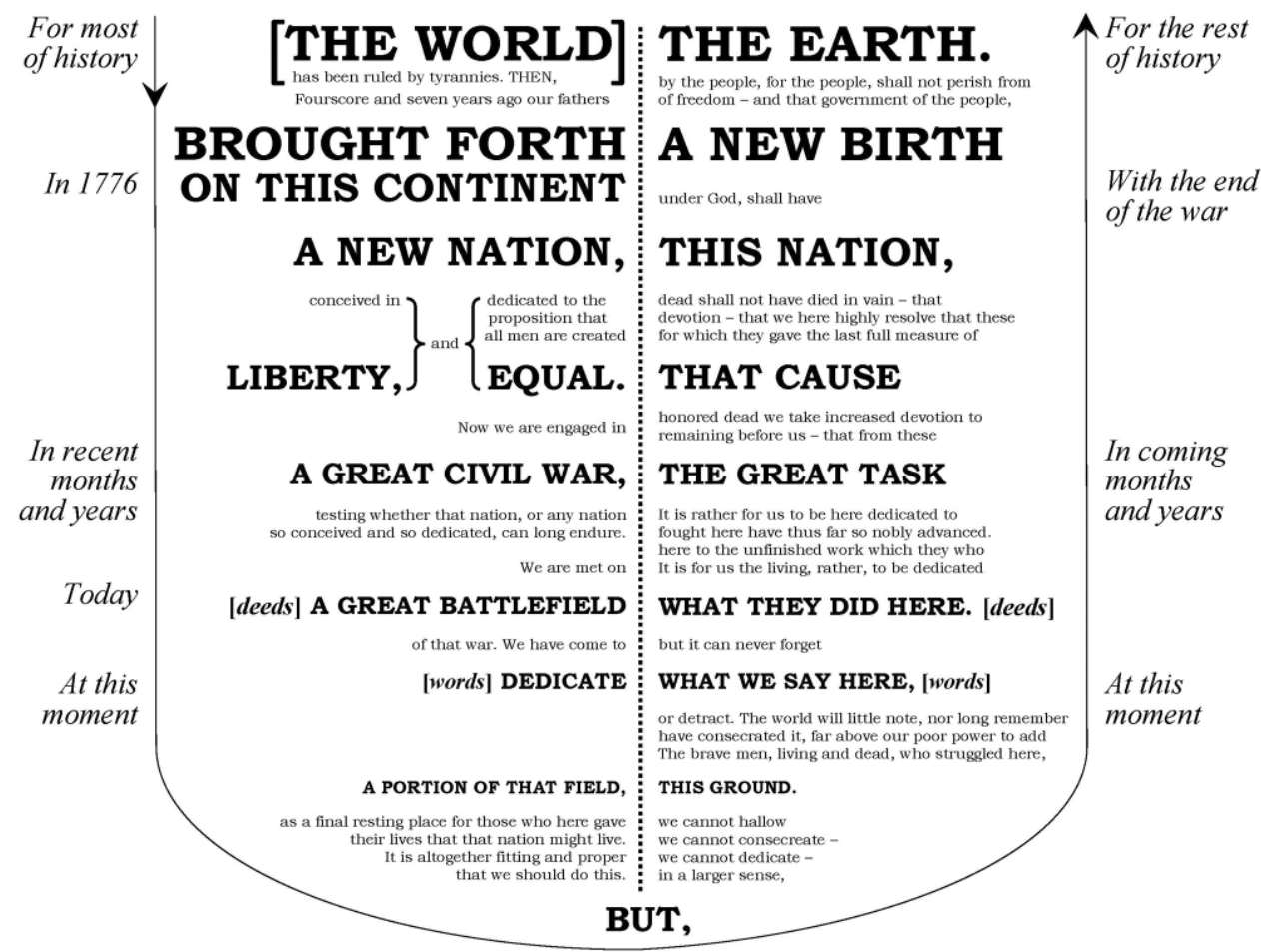

Figure 2. The U-shaped structure of the Gettysburg Address 
the address itself, when "we are met" on a narrower plot of ground: one of the war's most important battlefields. A still narrower "portion" of that field is to be dedicated to the memory of the men who fell and are buried there. That is the immediate task of the moment, the act that Lincoln and his audience are actually present to perform.

Then, beginning with the word "But," the movement reverses. (The right side of the diagram now reads "upwards.") Having just affirmed that a gathering to dedicate the field is "fitting and proper," Lincoln now declares that "in a larger sense" it is beside the point. Explaining this, he unfolds that larger sense through the same levels but in the opposite order. First, he recalls what happened on this ground: the battle and the sacrifice it involved. The consecration was already achieved on those recent days. Hence what really remains for "us, the living," occupying that ground at this moment, is not just to speak these commemorative words but to re-commit to the broader, near-term effort of which the battle was one part - that is, the great Civil War, finishing which is now "the great task" of coming months or years. As Lincoln had said moments earlier, the war represents a broader "testing," and he and his listeners are the ones being tested; on them depends the survival of those historically unique values of liberty and equality. Since these were the founding values of the nation, vindicating them will mean giving that nation "a new birth of freedom," mirroring its formal birth fourscore and seven years earlier. This new birth, finally, will not just restore or even improve the nation itself, but will secure the founding values, the viability of "government of the people, by the people, for the people," for humankind as such, and for the rest of foreseeable time.

In Lincoln's telling, then, one tiny plot of ground, and the momentary task of speaking some words over it - passing words of "poor power," words that the world will little note nor long remember - is the fulcrum of all human history, the decisive moment at which, following the fallen soldiers' inspiring example, listeners can take the step whose ultimate outcome will be saving the world from tyranny. The official act, in itself, is effectively useless: these mere words cannot dedicate, consecrate or hallow. What they might do is spur Americans on to their greater duty, which is to win the war, allowing the nation to carry on the still greater duty for which it was founded.

Thus, like a great speech emerging on a bit of discarded bookwrap, the widest possible meaning unfurls from the meager effort of a moment. Lincoln aligns these differently weighted events with the different shades of meaning in the word dedicate, on which he almost puns: the inert and backward-looking act of dedicating a memorial to the dead is an occasion for us, the living, to (re-) dedicate ourselves actively to the greater cause of a nation which was, itself, founded in dedication to the highest causes in political life.

Lincoln may not have known that his brief "Remarks" would become secular scripture, but the scriptural design of the address is evident in ways that go beyond its biblically resonant phrasings. Its two parts imitate the biblical Old and New Testaments as Christians were accustomed to reading them, with an earlier story of promise matched point-by-point to a later story of fulfillment. As 
Northrop Frye has demonstrated at length, this structure of "type" and "antitype," which he calls "U-shaped," is the Bible's "overall containing form" as well as the shape of many of its individual stories. ${ }^{6}$ Within it, the movement that Lincoln rhetorically traces - a descent from the highest plane of human endeavor to the humblest plot of earth, where suffering and death are experienced but vindicated, prompting a re-ascent to a future, more permanent victory - follows a sequence that his Christian listeners would recognize from familiar episodes in the life of Christ: Incarnation, Passion, Resurrection, Ascension.

These events, in turn, are key moments in "sacred" or "salvation" or "providential" history, an effort to fit world events into a gradually unscrolling plan or pattern ordained by God. Christians had long taken God's guiding hand in history as a given, but the mostly Reformed Protestants who settled and founded America, and whose theology held the Bible's authority especially high, were more eager than most to situate their own experience in relation to sacred history's grand overarching drama. As Mark A. Noll puts it,

the Bible was not so much the truth above all truth as it was the story above all stories. On public occasions Scripture appeared regularly as a typical narrative imparting significance to the antitypical events, people, and situations of United States history. That is, ministers preached as if the stories of Scripture were being repeated, or could be repeated, in the unfolding life of the United States. ... In the years between the American Revolution and the Civil War, the Bible offered to many Americans a key for understanding not only private religious reality but the public life of the country. $(1982: 43,51)$

As a storehouse of paradigms, archetypes and "the controlling myth for American experience," says Noll, "the Bible was woven into the warp and woof of American culture" and "had worked itself into the foundation of national consciousness," albeit at times to sharply opposed political purposes (1982: 45-46).

Christian sacred history held that the world's direction was ultimately progressive, although with episodes of rising and falling action all along the way. Humankind's story begins with a perfect Creation and original Fall from Grace, and it culminates in a final, climactic end, an Apocalypse that is also the passage into a newly perfected and eternal state. In between, God's "Chosen People" - bearers of his special promise or "Covenant," and claimants to a divinely appointed home, a "Promised Land" - experience various ordeals (temptation, testing, bondage, exile, wanderings in the wilderness) and moments of rescue (the Flood and the ark, the Exodus from Egypt, the return from Babylonian Captivity and rebuilding of the Temple). These are all types or prefigurations of the ultimate rescue: God's own Son becoming human, suffering, and dying as redemption for the sins of the world, then rising again in a final victory over sin and death. That decisive moment is the hinge on which the fate of the whole cosmos turns.

Yet, very importantly, most of the players in this immense drama are common people, mere humble sinners, often from society's lowest ranks. Its events take place in our own historical time, the most crucial of them some ninescore decades 
before Lincoln, in such unremarkable settings as a manger, an upper room, a road, a hill, and a garden on a particular Sunday morning. Christianity sees salvation as "new birth" and predicates it on a great but historically specific act of sacrifice. It promises this new birth to the faithful - no longer just the children of Israel, the "Chosen" of the Old Covenant, but literally anyone - if, in their own moment of decision, they too highly resolve to take the saving message they receive locally and deliver it to the rest of the world.

That Lincoln evidently had all this mind in writing the address does not, by itself, explain its rise to the first rank of the patriotic canon. Obviously the context was vastly important: Gettysburg was the decisive battle in a war whose outcome, in turn, was decisive for the nation's future. Given a high view of America's mission, analogizing that battle and the sacrifices it entailed to the saving sacrifice at the center of Christian history would have struck Lincoln's hearers as plausible, even expected. They had long been accustomed to speeches and sermons on great national occasions quoting and alluding to the Bible, presenting biblical characters and tales as exempla, and drawing parallels between contemporary events and those recorded in Scripture. Everett's Gettysburg oration, for instance, recalled the battle's aftermath, and the plight of the wounded and dying, as follows:

One drop of balm alone, one drop of heavenly life-giving balm, mingles in this bitter cup of misery. Scarcely has the cannon ceased to roar, when the brethren and sisters of Christian benevolence, ministers of compassion, angels of pity, hasten to the field and the hospital, to moisten the parched tongue, to bind the ghastly wounds.... When since Aaron stood between the living and the dead was there ever so gracious a ministry as this? .... Yes, brothers, sisters of charity, while you bind up the wounds of the poor sufferers, - the humblest, perhaps, that have shed their blood for the country, - forget not WHO it is that will hereafter say to you, "Inasmuch as ye have done it unto one of the least of these my BRETHREN, ye have done it unto me.” (Everett 1863: paragraph 38, emphases in original)

The same audience that would register the biblical cadences in Lincoln's address would certainly have recognized the many biblical phrases and tropes in Everett's. ("Binding up wounds" would figure importantly in Lincoln's own Second Inaugural.) Both speakers were drawing on long-established ways of infusing words with what they could hope, to Americans of the time, would be the greatest possible depth and power.

What distinguishes the Gettysburg Address, by comparison, is partly how short it is: the entire speech is substantially shorter than the single paragraph of Everett's that includes those quoted lines. This was not because Lincoln was simply a man of fewer words; he too was capable of speaking in public for hours at a time, as he had done during the famous Lincoln-Douglas debates. It seems, rather, to be a case of Lincoln turning the brevity suggested by the genre - "Remarks," not "Oration" - to deliberate strategic effect. In its extreme structural compression, the address presents the biblical message as a whole in microcosm. Copying the point-by-point symmetry of the two Testaments and their mirroring of type with 
antitype, it rapidly recapitulates each of the key elements of sacred history: a moment of creation at the start, and a promise of ultimate fulfillment in a fully achieved state at the end; a chosen nation struggling in a fallen world, in danger of failure but pressing on; a redemptive sacrifice, with a local setting and an instant in time on which a great destiny depends; and a call to take up that spirit of sacrifice in one's own life, thereby carrying the mission to completion. Transposing the Christian cosmic drama into the present, and recasting America, its soldiers and its citizens in the leading roles, Lincoln does not merely draw parallels; he frames the actions of Americans as synecdoches of the great events that Scripture presents as saving the world. All this is done at a length no greater than that of a typical biblical parable or psalm. The address is a kind of Scripture writ small, like one of the ultra-miniature "thumb" Bibles that were in vogue at the time. Its very brevity allows the whole biblical scheme to be taken in at once, as if it were an urgent dispatch just received by telegraph. These are qualities that a leisurely two-hour disquisition like Everett's, whatever its other virtues, was bound to lack.

They also highlight the fact that this message is not meant just to be passively absorbed. Like a telegraphed order, it must be acted on. In the Christian vision, everything depends on performance. Logically, a God of the whole universe could save the world without taking human form or relying on people's own agency, and there are "Gnostic" and other officially heretical variants of Christianity that ignore the biblical stories, deny the role of mundane events or the human personhood of Christ, and place little emphasis on the actions of individuals, apart perhaps from a secretly instructed spiritual elite. The Christianity that Lincoln and his listeners knew, by contrast, lends immeasurable importance to those elements of the everyday. The cosmic drama it claims to reveal depends on individuals who, like Lincoln but even more so, are "rough-hewn": fishermen, tax collectors, shepherds, servants, publicans, prostitutes. Though the passing thoughts and actions of these humble folks happen in ephemeral time, they have consequences on which even God pauses and waits (Auerbach 2003: 40-49). Christian faith strongly emphasizes what ordinary people choose to do, and it makes urgent demands on them to choose rightly.

So it was with Lincoln's widely noted and long-remembered words. His reference to the poor power of these resembles a standard speechmaker's faux-modest apology, the kind that Everett makes too in referring to his own "poor voice." For Everett, though, the speaker's inadequacy contrasts with his duty to rise to the occasion and speak nonetheless. The contrast that Lincoln draws is between words and performance. Ephemeral speech - his own, Everett's, that of "us, the living" in general - is inadequate to the great sacrifices made on the battlefield. The great task ahead now calls for further such deeds, and the words are a summons to these, a challenge to the nation like a biblical prophet's. They sit at the "bottom" of the U-shape, the junction point of the two-part structure, the moment where past gives way to future. Receiving the words positions Lincoln's listeners on the same moral continuum as the fallen soldiers - and back of that, the Founders and the America they intended to make. In one of his first public statements 
as president-elect, Lincoln had told well-wishers that saving the Union was more their business than his: "not with politicians, not with Presidents, not with officeseekers, but with you, is the question: shall the Union and shall the liberties of this country be preserved to the latest generations?" (Stampp 1964: 192). The challenge he issues in the Gettysburg Address is similar but larger, a reminder that the radical new potential for liberty and equality that America modeled for the world would not succeed, or even survive, unless ordinary Americans now took up the parts assigned them in the grand scheme. On battlefields like Gettysburg, the way had been shown. As in Christian thought, with its saints and martyrs as well as Christ himself, there were exemplary lives and deaths to look to, and it behooved the faithful to take the further actions that would give those sacrifices meaning in the present.

Although, again, there is nothing unusual in a public speaker hoping to inspire people to act, Lincoln's way of connecting words and deeds extends into a further dimension. It expresses a large theme, a view of political effectuality that was a key premise of much of his public career. Lincoln's lifelong political project, as many historians have seen it, was reading - and helping make - American history as the gradual effort to bring the abstract higher principles announced at the Founding, and specifically a certain high interpretation of them, into practical effect in the America that lay at hand. Garry Wills, for instance, sees in the address a "dialectic of ideals struggling for their realization in history." This in turn, he says, reflects Lincoln's debt to "the primary intellectual fashion of his period, Transcendentalism," which reached Lincoln through the historian George Bancroft as well as his own law partner, William H. Herndon, a "disciple" of the Transcendentalist and radical abolitionst Theodore Parker:

Bancroft, who had imbibed the elements of Transcendentalism from [theologian] Friedrich Schleiermacher in Berlin, expressed his political creed in the 1854 lecture: "In public life, by the side of the actual state of the world, there exists this ideal state toward which it should tend." The historian's task, he felt, is to follow "the clashing between the fact and the higher law." In the case of the United States, this meant tracing the fulfillment of the great American idea enunciated in the Declaration of Independence. (Wills 1992: 105)

Similarly, says Wills, Parker

saw the world progressing toward the realization of the supreme value, human freedom. For him there were four great leaps forward toward the realization of that ideal - the birth of Jesus, the Protestant Reformation, the puritan societies of New England, and the Declaration of Independence. In each case, mere fact is made to express, at last, transcendent aspirations and ideals. (1992: 109)

Analogizing this view to the Christian idea of the Kingdom of God, "Parker drew his all-important theological-political analogy: as Jesus is to the Bible (the ideal to the limited reality), so is the Declaration to the Constitution," which was the 
means to the Declaration's end, albeit a badly compromised one insofar as it permitted slavery (Wills 1992: 108).

It may be that Wills is assigning a bit too much importance to Parker. As a young state legislator, Lincoln was already celebrating the Declaration as a centerpiece of America's "political religion" - his emphasis - when Parker's preaching career was just beginning (Lincoln 1838). There were many roads, as it were, to Gettysburg. Motivating action in service of larger principles or goals is hardly unique to the Gettysburg Address; it is the point of much lesser political speeches ("Vote for me so we can make America great again"), as is the task of rallying citizens to persevere through wars and other great struggles. Further, even without any Transcendentalist influence, Lincoln might well have arrived at his political philosophy just from the pressure of events. Speaking for an upper Midwestern constituency that had solid material reasons for wanting slavery restricted, he re-entered politics in 1854 amid the great national debate over the Kansas-Nebraska Act, a debate that turned in part on clashing readings of the Declaration and its "self-evident" premise that "all men are created equal." Was that statement simply wrong, as John C. Calhoun and other slavery advocates claimed? Was it meant to refer only to whites or to Englishmen, a reading consistent with the Founders' own continued slaveholding? Was it a rhetorical flourish gratuitously added to a document more narrowly intended as a legal notice and press release? Was it cynical posturing, even a lie, as some angry abolitionists saw it? Or was it a ringing assertion of the values underlying and justifying the constitutional order in the first place, the key to the Founding itself and to America's continuing revolutionary purpose? These competing views of the Declaration were all current in Lincoln's time (Maier 1998: 191-208).

In coming to the latter conclusion - and helping turn it from contested claim into America's received wisdom - Lincoln encamped with the likes of Parker and his abolitionist jeremiads, even if, as a practical politician, he carried on more circumspectly. On this point, though, he may not have been following Parker so much as drawing from the same, very old reservoirs of American idealism. Visions of a higher perfection, calls to have faith in it and to act on it in the here and now, and the resulting idea of one special people's messianic mission to the rest of the world were all readily available to Lincoln even without being decanted through the special enthusiasms of the Transcendentalists. To the contrary, the outlook expressed in his rhetoric had been shaping Americans' vision of their country and its historic role since long before Lincoln was even born.

There is another sense, however, in which the Transcendentalists can help us understand the address. In carefully patterning the ephemeral message of a moment on sacred history, even to the point of creating a simulacrum of the Bible itself, Lincoln was obviously attempting to borrow authority for his message from the most revered of his culture's texts and traditions. At the same time, a secularized performance like this lends the texts and traditions something in return, lifting the cosmic drama they describe out of the pages of a very old book and giving it the practical urgency of real and deeply felt present events. Lincoln makes his words a kind of prism, a means of diffracting the undifferentiated white light of 
ethereal truth into the recognizable colors of the real world, where they can and must be acted upon in the specific historical circumstances of the moment. Borrowing from but also applying scriptural tropes, he demonstrates another means of replacing a "dead letter," as Ralph Waldo Emerson had once put it, with a "perpetual Scripture" (1833, 1910: 225).

In this he is doing the work of the prophet or "new Teacher" the Transcendentalists had called for, the "divine literatus" in Walt Whitman's phrase (Emerson 1838; Whitman 1871: 932). The power to "vivify" the otherwise inert (Whitman 1871: 987), including the "antique" literary expressions of ages past (985n), was for Whitman the difference between great poets - the "orbic bards" whom America now awaited (974), and who would play a role like that of its presidents, only better (1855: 8) - and the conventional writers of the "old track" (1871: 975) who serviced the mass public's urge "to rhyme and to read rhyme" (974) by delivering "poems distilled from other poems" (1855: 26). As an excellent example of such derivative work, we have the versified revision that one conspicuously non-divine literatus gave the Gettysburg Address in 1869:

\footnotetext{
Let us, the Living, rather dedicate

Ourselves to the unfinished work, which they

Thus far advanced so nobly on its way,

And save the perilled State!

Let us, upon this field where they, the brave,

Their last full measure of devotion gave,

Highly resolve they have not died in vain!-

That, under God, the Nation's later birth

Of freedom, and the people's gain

Of their own Sovereignty, shall never wane

And perish from the circle of the earth!
}

Embedded within a longer poem, this "Gettysburg Ode" (Taylor 1869) copies Lincoln's phrases but scrambles their order. This allows for facially poetic structuring - meter and rhyme - but at the cost of the deeper, more forcefully expressive structure of type and antitype that was Lincoln's key to the meaning of events.

A different lyric that makes for a more worthy comparison is "The Battle Hymn of the Republic," which would enter the American musical canon as one of its best-known patriotic songs. Julia Ward Howe's lyrical borrowings from Scripture are even denser than Lincoln's, with virtually every phrase a quote or allusion: "trampling out the vintage" and "grapes of wrath" from Jeremiah 25 and Revelation 14 and 19; a "terrible, swift sword" from Isaiah 27; "crush the serpent with his heel" from Genesis 3, and so on. This parade of warlike images, chosen from the Bible's most combative texts and pounded home with the borrowed tune's relentless cannon-fire stresses, is charged with a stridency that the Gettysburg Address seemingly lacks. For Garry Wills, "Nothing could be farther from 
the crusading righteousness" of Howe's lyrics than Lincoln's seemingly gentler mode. His "submission to Providence is made in a spirit of humility, reflected in the series of Fast Day and Thanksgiving Day proclamations issued throughout the war, where the people as a whole are called on to repent the sins that led to violence" (1992: 184). Lincoln's tone at Gettysburg was somber, not aggressive, as befitted the occasion: He was dedicating a cemetery.

Those differences in tone, however, are misleading. From the standpoint of performance, the works are fundamentally similar. Howe's patchwork pastiche of biblical quotes would not be intelligible at all without context - if not that of the Civil War itself, then more broadly that of a militant, religiously styled political mission to the world, which is how Americans seem to receive the "Battle Hymn" today (Tierney 2010). Indeed the lyrics make the most sense as what originally inspired Howe: words accompanying soldiers literally on the march, already in motion en route to enacting in the present and visible world the metaphors drawn from the prophets of old (Howe 1899: 273-276). That performative situation, or the imagining of it, gives the scriptural allusions their meaning.

Similarly, in context, Lincoln's quieter words are also a kind of battle hymn. It is true that at times he presented the war as recompense for the sin of slavery, most famously so in his Second Inaugural Address. Yet even there, this "mighty scourge" was not one that Americans just passively underwent, like a natural disaster. It was something that both sides had "sought to avert" but, nonetheless, had ultimately chosen, and must therefore "strive on to finish" (Lincoln 1865). By the time of Lincoln's Second Inaugural, moreover, the war's destruction was nearly complete; when Lincoln was speaking at Gettysburg, more than a year earlier, a significant fraction of it was still to come. Though he phrased it obliquely, what the high resolve and "unfinished work" he referred to meant in practice was ruthless military force - operations like General Sherman's "March to the Sea," a scorched-earth and distinctly wrathful campaign in which wide swaths of southern territory would quite literally be "trampled out." Unlike Edward Everett, who closed his address on a sentimental vision of eventual reunion, Lincoln was steeling his listeners for the harsh and dangerous fighting ahead. Softer phrasings aside, his words are closer in their tacit militancy to Howe's.

Finally, it must be said that to view the Gettysburg Address as performance is to situate it within the vast Lincoln mythography, the immense weight of cultural meanings that Americans came to assign to Lincoln's own person. ${ }^{7}$ As we can see in stories like The Perfect Tribute and many others, the sacrelization of the address and the sacrelization of Lincoln were joint and mutually reinforcing developments. Not only did Lincoln's assassination make him a martyr to the cause himself - the symbolic "last casualty" of the war, as many eulogists put it (Hodes 2015: 196) - but with uncanny timing it occurred on Good Friday, another day of dedication, hallowed in Christian understanding by the saving sacrifice of Christ.

The Gettysburg Address thus became oddly and personally prophetic, a foreshadowing of Lincoln's own vivid if unintended re-enactment of a central event of sacred history. As one early commentator put it, looking back at Gettysburg 
in light of Lincoln's recent death, Lincoln's listeners "were fully conscious that he was the greatest actor in all the drama" (Arnold 1866: 424). Walt Whitman developed the same theme at length in a popular public lecture he delivered on several occasions between 1879 and 1890 , usually by way of marking the assassination's anniversary (Wood 2009). It was ironic, says Whitman, that Lincoln was shot while watching actors in a conventional and forgettable play, when he himself was "in some respects the leading actor in the stormiest drama known to real history's stage through centuries":

Why, if the old Greeks had had this man, what trilogies of plays - what epics - would have been made out of him! How the rhapsodes would have recited him! How quickly that quaint tall form would have enter'd into the region where men vitalize gods, and gods divinify men! (Whitman 1879: 1041, 1046)

John Wilkes Booth, the actor-assassin, had intended the moment as high drama, Whitman observes, and had obviously even rehearsed it, though its true meaning was lost on him (1879: 1043).

Strikingly, Whitman's own route to that meaning runs through journalism. Before proceeding with interpretations that spare no superlatives, Whitman devotes a long section of his lecture to a matter-of-fact account, based on eyewitness reports, of the actual events in and around Ford's Theater - "the visible incidents and surroundings of Abraham Lincoln's murder, as they really occurred" - including such otherwise insignificant, newspaper-like details as Booth making his escape by crossing the stage diagonally (1879: 1041-1044). We find the momentous in the seemingly minor, Whitman suggests - like the fact that lilacs were then blooming, a memory on which he had based one of his most famous poems (Whitman 1865). Even the fatal moment itself was oddly ordinary:

Great as all its manifold train, circling round it, and stretching into the future for many a century, in the politics, history, art, \&c., of the New World, in point of fact the main thing, the actual murder, transpired with the quiet and simplicity of any commonest occurrence - the bursting of a bud or pod in the growth of vegetation, for instance. (Whitman 1879: 1042)

What impresses Whitman is the enormous quantity of meaning that emerges from one "simple, fierce deed," and how much of history can turn upon it: a "long and varied series of contradictory events," the many "bloody and angry problems" of the whole, prolonged secession period, "arrives at last at its highest poetic, single, central, pictorial denouement," one of the "climax-moments" that ring down the curtain "on the stage of universal Time" (1879: 1045).

For Whitman this was ultimately a relief, at least in one respect. Lincoln's death may have been tragic, but it was tragedy in the great classical sense, one of those "dramatic death" on which the creation of "a Nationality" depends (1879: 10461047). Because "the immeasurable value and meaning of that whole tragedy lies, to me, in senses finally dearest to a nation, (and here all our own) - the imaginative 
and artistic senses - the literary and dramatic ones," a death like Lincoln's, which "outvies" even other great deaths like Socrates' and Julius Caesar's, guaranteed that America's own stories would rank at least as highly as other nations' in the world's literary canon. Hence it was further assurance against the driving anxiety, still present to a leading poet's mind as late as the 1880 s, that America might yet come up short in literary achievements. "How the imagination - how the student loves these things! America, too, is to have them" (1879: 1045):

\footnotetext{
A great literature will yet arise out of the era of those four years [of Civil War], those scenes - era compressing centuries of native passion, first-class pictures, tempests of life and death - an inexhaustible mine for the histories, drama, romance, and even philosophy, of peoples to come - indeed the verteber of poetry and art, (of personal character too,) for all future America - far more grand, in my opinion, to the hands capable of it, than Homer's siege of Troy, or the French wars to Shakspere. (sic, 1879: 1040)
}

For Lincoln himself, the drama of universal Time was staged on battlefields like Gettysburg; it was there that ideals entered history and human actions revealed the sacred - men vitalizing gods and gods divinifying men, as Whitman puts it (1879: 1046). For Whitman this had happened on an even grander scale in Lincoln's own life and death.

Whitman, though, was a rhapsodist, not a biographer. Though he reported having glimpsed Lincoln in person on many occasions, the figure he describes is less a living man than a neoclassical abstraction. The "quaint tall form" he conjures in his lecture (1046) resembles the idealized, nearly godlike "Type of American Genius" that a much lesser poet made of Lincoln in a long epic poem (Blanchard 1882). By contrast, William H. Herndon, the onetime law partner of Lincoln's who did know him well, and who also lectured on him frequently in the years after his death, emphasized the less elevated kinds of details that might be called "novelistic," in two senses: they read like, and at times possibly were, fiction. Among the tales Herndon collected and published that became favorite bits of the Lincoln legend, for instance, is the famous story of young Abe's doomed love for Ann Rutledge, an episode that remains undocumented apart from Herndon's own much later reconstruction. ${ }^{8}$ Though prettified in $20^{\text {th }}$-century retellings, the story as Herndon gave it pictured a 26-year-old Lincoln "plunged in despair" over Ann's untimely death almost to the point of insanity (Herndon 1888: 139).

Herndon was criticized for trafficking in stories like this, stories which, even (or especially) if true, might be thought unseemly or scandalous by Victorian standards, and in some cases might reveal Lincoln's faults. His defense against this charge was notably modern and, at the same time, old-fashioned, a window onto the era's changing views of where authority was to be found. In admitting to what might be "ghastly exposures," he insisted repeatedly on the importance of uncolored, unsuppressed facts, "the real data" about Lincoln the person. If Lincoln was truly to live in memory, "We must have all the facts - we must be prepared to take him as he was." According to Herndon, one of Lincoln's closest friends had urged him 
on, suggesting that he model his Lincoln biography on the only "true history" ever written, the only one that presented "the whole truth - the inner life" of its subjects. "The heart and secret acts are brought to light and faithfully photographed" in this book alone, a book that Herndon agreed his volumes of "collected data" on Lincoln would do well to mimic (Herndon 1888: vii-xii). That book was the Bible.

\section{Notes}

1 Address Delivered by Abraham Lincoln at the Dedication of the National Cemetery, Gettysburg, Pennsylvania, November 19th, 1863 (Boston: Tudor Press, 1919), http://www. archive.org/details/addressdeliveredlinc. For other efforts in this vein over the years, see "Lincoln's Gettysburg Address in Print" (2016).

2 In reviewing other scholarship on the address, Elmore (2009: 14-17) notes surprisingly little attention to its religious features - though see also Dreisbach for another discussion of these elements, as well as LaFantasie's (1995) comparison of the event at Gettysburg to a religious "awakening," "revival" or "camp meeting." Contrarily, argued an earlier critic, Glen E. Thurow, "The similarities of language and style to the Bible by themselves prove nothing about the religious qualities of Lincoln's speech." In Thurow's ingenious analysis, what matters most is Lincoln's recourse to the geometrical terminology of axioms and proofs. Thurow (1976: 69) and chapter 4.

3 Boritt (2006: 81-83); Elmore (2009: 17-18), Donald (2011: 460-461). Peterson (1994) summarizes the legend and its origins on pages 114-116. For a book-length account, see Johnson's Writing the Gettysburg Address, especially chapter 3 on the train legend. Isaac N. Arnold's report that Lincoln was not asked for remarks until already "on his way" (1866: 422 ) is almost certainly false, since the programs that listed them must have been printed by then. As to what actually happened on the train, it could be that someone saw Lincoln in some late stage of work on the text and mistook this for a hurried first drafting.

$4 \quad$ The actual response of Lincoln's original audience is a matter of sharply conflicting reports. See LaFantasie (1995), 80-83. Arnold was perhaps exaggerating in the other direction when he wrote that "the words arrested attention, and instantly the magnetic influence of a grand idea uttered by sympathetic nature pervaded the vast assembly ... his hearers were fully conscious that he was the greatest actor in all the drama, and that he was uttering words which would live as long as the language. The magnetism of those who heard him, extended to the vast crowds beyond the reach of his voice, and tears, and sobs, and cheers, spoke the emotions which deeply moved the assemblage, with grand, patriotic, heroic thoughts, the sublime in action and sentiment" (Arnold 1866: 423-424).

5 Figure 2 and the analysis that follows rely on the text of the address at Voices of Democracy: The U.S. Oratory Project, University of Maryland, http://voicesofdemocracy.umd.edu/ lincoln-gettysburg-address-speech-text/. Spellings are modernized. For the variants among the extant manuscripts, see "The Gettysburg Address," Abraham Lincoln Online: Speeches and Writings, http://www.abrahamlincolnonline.org/lincoln/speeches/gettysburg.htm.

$6 \quad$ See Frye and Macpherson, Biblical and Classical Myths (2004: 22-23 and chapter 2), and Frye, The Great Code (1990: 79, 128, 169-171 and chapters 4 and 5). Donald says the address has "an hourglass form" (2011: 461), which is also correct but misses the biblical parallels as did other critics: Donald also notes that an opposition newspaper mocked Lincoln's birth and rebirth imagery as "obstetric analogies" (462).

7 Smith (2009: 84-96, 113-119, 150-155). For book-length discussions of this phenomenon, see Peterson (1994) and Fox (2015).

$8 \quad$ For a review of the evidence and the Rutledge legend's changing scholarly reputation, see Gannett (2005: 28-41). For the Rutledge story itself, see Herndon and Weik (1888), chapter VI. 


\section{References}

Address of Hon. Edward Everett, at the Consecration of the National Cemetery at Gettysburg, $19^{\text {th }}$ November, 1863, with the Dedicatory Speech of President Lincoln, and the Other Exercises of the Occasion [the official program]. Boston: Little, Brown \& Co., 1864.

Andrews, Mary Raymond Shipman (1906) The Perfect Tribute. New York: Charles Scribner's Sons.

Arnold, Isaac N. (1866) The History of Abraham Lincoln, and the Overthrow of Slavery. Chicago: Clarke \& Co.

Auerbach, Erich (2003) Mimesis: The Representation of Reality in Western Literature, trans. by W.R. Trask, $50^{\text {th }}$ anniversary edition. Princeton, NJ: Princeton University Press.

Blanchard, Rufus (1882) Abraham Lincoln, The Type of American Genius: An Historical Romance. Wheaton, IL: R. Blanchard \& Co.

Boritt: Gabor (2006) The Gettysburg Gospel: The Lincoln Speech That Nobody Knows. New York: Simon \& Schuster.

Donald, David Herbert (2011[1995]) Lincoln. New York: Simon \& Schuster.

Dreisbach, Daniel (2013) The Sacred Sounds of Lincoln's Gettysburg Address (19 November 2013). Online Library of Law \& Liberty, http://www.libertylawsite.org/2013/11/19/thesacredsoundsoflincolnsgettysburgaddress/.

Elmore, A.E. (2009) Lincoln's Gettysburg Address: Echoes of the Bible and the Book of Common Prayer. Carbondale, IL: Southern Illinois University Press.

Emerson, Ralph Waldo (1910) 24 October 1833. Journals of Ralph Waldo Emerson, 1820-1872, Vol. III: 1833-1835. Ed. Edward Waldo Emerson and Waldo Emerson Forbes. Cambridge, MA: Riverside Press.

Emerson, Ralph Waldo (1838) Divinity School Address (15 July 1838). Emerson Central, https:// emersoncentral.com/texts/nature-addresses-lectures/addresses/divinity-school-address/.

Everett, Edward (1863) Gettysburg Address (19 November 1863). Voices of Democracy: The U.S. Oratory Project. University of Maryland, http://voicesofdemocracy.umd.edu/everett-gettysburgaddress-speech-text/.

Fox, Richard Wightman (2015) Lincoln's Body: A Cultural History. New York: W.W. Norton.

Frye, Northrop and Jay Macpherson (2004[1962]) Biblical and Classical Myths: The Mythological Framework of Western Culture. Toronto: University of Toronto Press.

Frye, Northrop (1990[1983]) The Great Code: The Bible and Literature. New York: Penguin Books.

Gannett, Lewis (2005) 'Overwhelming Evidence' of a Lincoln-Ann Rutledge Romance?: Reexamining Rutledge Family Reminiscences. Journal of the Abraham Lincoln Association 26(1).

Herndon, William H. and Jesse William Weik (1888) Abraham Lincoln: The True Story of a Great Life, Vol. 1. Springfield, IL: The Herndon's Lincoln Publishing Company.

Hodes, Martha (2015) Mourning Lincoln. Yale University Press.

Howe, Julia Ward (1899) Reminiscences, 1819-1899. Boston and New York: Houghton Mifflin.

Johnson, Martin P. (2013) Writing the Gettysburg Address. Lawrence, KS: University Press of Kansas.

LaFantasie, Glenn (1995) Lincoln and the Gettysburg Awakening. Journal of the Abraham Lincoln Association 16(1).

Lincoln, "The Perpetuation of Our Political Institutions" (27 January 1838). Journal of the Abraham Lincoln Association 6:1 (1984), 10, http://hdl.handle.net/2027/spo.2629860.0006.103.

Lincoln, "Second Inaugural Address" (4 March 1865). The Avalon Project, Yale Law School Library, http://avalon.law.yale.edu/19th_century/lincoln2.asp.

"Lincoln's Gettysburg Address in Print" (13 June 2016). Lincoln Financial Foundation Collection, Indiana State Museum and the Allen County Public Library, http://incolncollection.tumblr.com/ post/145872657819/lincolns-gettysburg-address-in-print.

Maier, Pauline (1998) American Scripture: Making the Declaration of Independence. New York: Vintage / Random House. 
Noll, Mark A. (1982) The Image of the United States as a Biblical Nation, 1776-1865. In: Nathan O. Hatch and Mark A. Noll (eds.) The Bible in America: Essays in Cultural History. New York: Oxford University Press.

Peterson, Merrill D. (1994) Lincoln in American Memory. New York: Oxford University Press.

Poore, Benjamin Perley $(1885,1888)$ Reminiscences of Abraham Lincoln by Distinguished Men of His Time, $6^{\text {th }}$ ed., ed. Allen Thorndike Rice. New York: North American Review.

Smith, Jeff (2009) The Presidents We Imagine: Two Centuries of White House Fictions On the Page, On the Stage, Onscreen, and Online. Madison, WI: University of Wisconsin Press.

Stampp, Kenneth M. $(1950,1964)$ And the War Came: The North and the Secession Crisis, 186061. Chicago: University of Chicago Press.

Taylor, Bayard (1869) Gettysburg Ode (Dedication of the National Monument, July 1, 1869). Poetry Nook, http://poetrynook.com/poem/gettysburg-ode-0.

Thurow, Glen E. (1976) Abraham Lincoln and American Political Religion. Albany, NY: State University of New York Press.

Tierney, Dominic (2010) 'The Battle Hymn of the Republic': America's Song of Itself. The Atlantic, 4 November 2010. https://www.theatlantic.com/entertainment/archive/2010/11/the-battlehymn-of-the-republic-americas-song-of-itself/66070/.

Whitman, Walt. "Death of Abraham Lincoln" (1879, 1880, 1881). In: Kaplan, Justin (ed.) Walt Whitman: Complete Poetry and Collected Prose. New York: Library of America, 1982. EPUB file.

Whitman, Walt (1871) Democratic Vistas. In: Kaplan, Justin (ed.) Walt Whitman: Complete Poetry and Collected Prose. New York: Library of America, 1982. EPUB file

Whitman, Walt (1855) Preface. Leaves of Grass, $1^{\text {st }}$ ed. (Brooklyn, NY: N.p., 1855). The Walt Whitman Archive, Center for Digital Research in the Humanities, University of Nebraska - Lincoln, https://whitmanarchive.org/published/LG/1855/whole.html.

Whitman, Walt (1865) When Lilacs Last in the Dooryard Bloom'd (1865, 1891-1892). In: Kaplan, Justin (ed.) Walt Whitman: Complete Poetry and Collected Prose. New York: Library of America, 1982. EPUB file.

Wills 1992: Garry. Lincoln at Gettysburg: The Words That Remade America. New York: Simon \& Schuster.

Wood, Tara (posting as “taraw”). Visitor Center Script: Whitman's Lincoln Lectures (10 December 2009). Looking for Whitman, http://twood.lookingforwhitman.org/2009/12/10/visitor-centerscript-whitmans-lincoln-lectures/.

JeFF Smith teaches early American literature and Anglo-American political fiction and culture in the Department of English and American Studies at Masaryk University, Brno, the Czech Republic. He has a Ph.D. in English Language and Literature from the University of Chicago, has held Fulbright Fellowships for research and teaching, and has been a Visiting Fellow at the Rothermere American Institute, Oxford University. Among his previously published works are The Presidents We Imagine: Two Centuries of White House Fictions on the Page, on the Stage, Onscreen, and Online (Studies in American Thought and Culture, University of Wisconsin Press, 2009).

Address: Jeff Smith, Deparment of English and American Studies, Faculty of Arts, Masaryk University, Arne Nováka 1, 60200 Brno, Czech Republic. [e-mail: smith@phil.muni.cz] 
